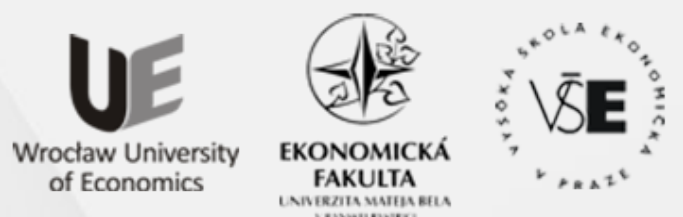

Conference Proceedings

Full TeXT PAPERS

edited by

Zofia Rusnak and Beata Zmyślona

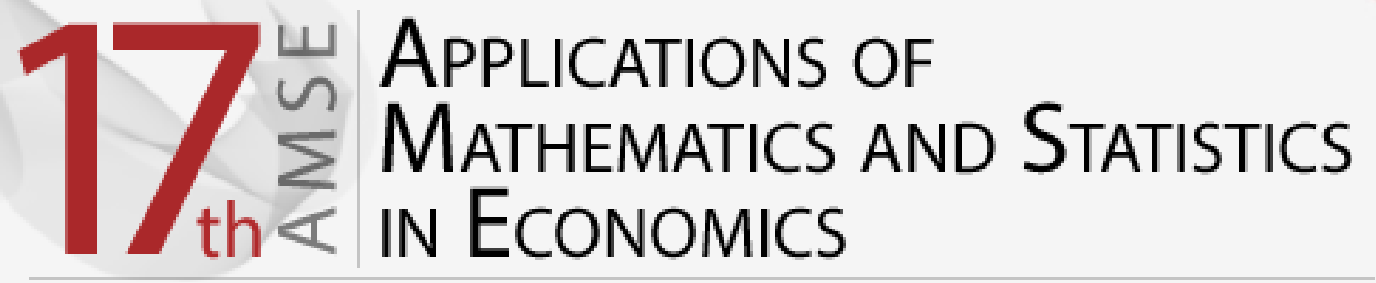

International Scientific Conference | Poland • 27-31 August 2014 
Scientific Committee

Richard Hindls, Stanislava Hronová, Rudolf Zimka, Walenty Ostasiewicz, Emília Zimková, Zofia Rusnak, Martin Bod'a

Organizing Committee

Beata Zmyślona, Cyprian Kozyra, Grzegorz Rogoziński, Kristýna Vltavská

\section{Reviewers}

Milan Bašta, Diana Bílková, Martin Bod'a, Joanna Dębicka, Tomáš Fiala, Jakub Fischer, Stanisław Heilpern, Karel Helman, Lenka Hudrlíková, Miroslav Hužvár, Nikola Kaspř́ková, Alena Kaščáková, Kamil Kladívko, Jindřich Klůfa, Pavol Král', Katarzyna Kuziak, Jana Langhamrová, Ivana Malá, Tomáš Marcinko, Luboš Marek, Miloš Maryška, Petr Mazouch, Zofia Mielecka-Kubień, Witold Miszczak, Petr Musil, Gabriela Nedelová, Walenty Ostasiewicz, Iva Pecáková, Viera Roháčová, Zofia Rusnak, Mária Stachová, Jana Špirková, Šárka Šustová, Jana Tepperová, Vladimír Úradníček, Kristýna Vltavská, Michal Vrabec, Dariusz Wawrzyniak, Henryk Zawadzki, Jaroslav Zbranek, Tomáš Zeithamer, Martin Zelený, Jan Zeman, Rudolf Zimka, Emília Zimková, Pavel Zimmermann, David Žižka

Layout

Martin Bod'a, Beata Zmyślona, Grzegorz Rogoziński

Front page design

Grzegorz Rogoziński

CD cover design

Beata Dębska

Articles published in the form submitted by the authors

All rights reserved. No part of this book may be reproduced in any form or in any means without the prior permission in writing of the Publisher

(C) Copyright by Wrocław University of Economics Wrocław 2014

ISBN 978-83-7695-421-9

Wydawnictwo Uniwersytetu Ekonomicznego we Wrocławiu

53-345 Wrocław, ul. Komandorska 118/120 www.ue.wroc.pl

Sprzedaż książek tel./fax 71 36-80-602

e-mail: econbook@ue.wroc.pl www.ksiegarnia.ue.wroc.pl 


\section{Contents}

Foreword

Diana Bílková: TL-Moments: Analogy of Classical L-Moments

Dagmar Blatná: Application of Robust Regression in the Analysis of Internet Access in European Countries

Martin Bod’a, Mária Kanderová: Rebalancing Issues in Tracking Error Variance Minimization

Martin Bod'a, Viera Roháčová: Application of Six Sigma Ideas to Timing Decisions at Financial Markets

Anton Dekrét, Rudolf Zimka: On the Price Hartwick's Task and Its Inverse in a Dynamic Model of an Economy with Exhaustible Resources

Joanna Dębicka, Agnieszka Marciniuk: Comparison of Reverse Annuity Contract and Reverse Mortgage on the Polish Market.

Petra Dotlačilová, Jitka Langhamrová: The Influence of Mortality Models for the Expected Future Life-time of Older People

Marek Ďurica, Lucia Švábová: Delta and Gamma for Chooser Options.

Vlastimil Farkašovský: New Concept of Pension Funds Performance Evaluation

Albert Gardon: The Normality of Weekly Relative Changes of the Freight Rate in Container Shipping.

Mária Grausová, Miroslav Hužvár, Jana Štrangfeldová: Healthcare Systems Efficiency in the Visegrád Group.

Stanisław Heilpern: Multiple Life Insurance - Pension Calculation

Alena Kaščáková, Gabriela Nedelová: Changes in Slovak Households' Economy

Igor Kollár, Pavol Král', Peter Laco: Methodology for Assessing Website Improvement in Corporate Environment.

Maciej Kostrzewski: Some Method of Detecting the Jump Clustering Phenomenon in Financial Time Series.

Cyprian Kozyra, Beata Zmyślona, Katarzyna Madziarska: Complementary Objective and Subjective Measures of Hospital Services Quality...

Pavol Král', Mária Stachová, Lukáš Sobíšek: Utilization of Repeatedly Measured Financial Ratios in Corporate Financial Distress Prediction in Slovakia

Ivana Malá: The Use of Finite Mixture Model for Describing Differences in Unemployment Duration

Lukáš Malec: Studying Economics and Tourism Industry Relations by Smooth Partial Least Squares Method Depending on Parameter. 
Tomáš Marcinko: Consequences of Assumption Violations Regarding Classical Location Tests.

Edyta Mazurek: The Income Tax Progression Depending on Social Insurance Contribution in Poland.

Petr Musil, Jana Kramulová, Jan Zeman: Regional Consumption Expenditures: An Important Starting Point for Regional Input-output Tables.

Katarzyna Ostasiewicz, Walenty Ostasiewicz: Good Life: From Political to Human Economy

Anna Sączewska-Piotrowska: Analysis of Poverty Transitions in Poland Using Multilevel Discrete-Time Event History Models

Martina Šimková, Petra Švarcová: Disadvantaged University Students in the Czech Republic.

Michal Široký: The Use of Short-term Business Statistics for Quarterly GDP Flash Estimates in the Czech Republic

Zdeněk Šulc, Hana Řezanková: Evaluation of Recent Similarity Measures for Categorical Data.

Lucia Švábová, Marek Ďurica: The Relationship Between the Finite Difference Method and Trinomial Trees

Kristýna Vltavská, Jaroslav Sixta: The Estimation of Final Consumption Expenditures

Lenka Vraná: Business Cycle Analysis: Tracking Turning Points

Janusz Wywiał: On Bayesian Testing in Auditing

Emília Zimková: Window Analysis of Supper-efficiency Change: Case of the Slovak Banking System ....

Beata Zmyślona: Statistical Modelling of the Impact of Diabetes on the Risk of Hospitalization 


\title{
DISADVANTAGED UNIVERSITY STUDENTS IN THE CZECH REPUBLIC
}

\author{
MARTINA ŠIMKOVÁ \\ University of Economics Prague, Faculty of Informatics and Statistics, Department of Demography, \\ W. Churchill Sq. 4, 13067 Prague 3, Czech Republic \\ email: martina.simkova@vse.cz \\ PETRA ŠVARCOVÁ \\ University of Economics Prague, Faculty of Informatics and Statistics, Department of Economic \\ Statistics, W. Churchill Sq. 4, 13067 Prague 3, Czech Republic \\ email: petra.svarcova@vse.cz
}

\begin{abstract}
Equal access to education is currently very often discussed and many educational programs are designed for children from socially disadvantaged families and or for disabled people. But how are these students studying at universities? Our paper is aimed at the analyses of disadvantaged students' study including people from socially disadvantaged families, disabled people or young mothers with children. The analysis contains the access of these students to the study, satisfaction with study and school, their living conditions and future plans. We also try to describe students' behaviour and to identify key problems of their study. The analysis also includes recommendation for universities how to improve the learning environment for these types of students and how to eliminate the problems that are usually invisible for "normal" students.
\end{abstract}

Key words: disadvantaged students, living conditions, satisfaction with the study

DOI: 10.15611/amse.2014.17.25

\section{Introduction}

Education is a primary way to reach success, each student should have a chance to excel, both in school and in life. Accessibility of education for students should be one of the goals of education; it should be obtainable for all students, regardless of income, social class, race or disability. The educational attainment is affected by many factors, e.g. socioeconomic status of family, parental education, living conditions, health, etc.

Tertiary education system in the Czech Republic went through a massive expansion during the last twenty years (Mazouch, Fischer, 2011), the increase of university students in the last ten years was by more than $70 \%$. It also increases the proportion of female students (CZSO, 2012).Although the number of students increased, the chances of attainment of tertiary education are not equal. The issue of inequality of access to education has been investigated from the early 1970s, e.g. Sewell (1971). Our paper deals with disadvantaged students' study including people from socially disadvantaged families, disabled people or young mothers with a child, and shows their study conditions. It can be assumed that the students with one of those disadvantages have less potential for graduating college than "normal" students.

The study conducted by Jencks (1973) showed the relationship among the inequality of level of education, occupational status, job satisfaction and income inequality. Jencks found that 
these issues are determined by family background. The social status of the family is determined primarily by parental education. Fischer and Lipovská (2013) showed the intergenerational transmission between parents and their children in the level of education. Cullinan et al (2013) shows the availability of university studies for students from low social class in Ireland.

The second "endangered species" of students are young women with children. There is no evidence about the number of women interrupting their studies due to motherhood in the Czech Republic. And also no analysis about study of women with children at universities is available. The study by Dömeová et al (2010) monitors the demographic situation and motivation for studying of women and men with children. Tiu Wu (2013) shows some selected problems of mothers at doctoral study programs. Previously, motherhood was a significant cause of leaving school, but nowadays women might often return to school to finish their education to improve their position in the labour market (Scott, 1998).

The last analysed group represents disabled students. Nowadays there is no specialized law regulating the education of disabled students at universities in the Czech Republic. However, the Ministry of Education, Youth and Sports supports some projects for developing of actual needs of disabled students. Riddell et al (2005) discussed the fairness in the distribution of social good and quality of cultural and educational issues in the UK. Hadjikakou (2012) shows the study of disabled students and their satisfaction with support in the UK. They find that participation of disabled students in tertiary education has achieved some progress in the last twenty years. As an example of progress in the Czech Republic, we can mention foundation for the study of disabled students ${ }^{1}$ or the creation of special centres which support disabled student at universities. Nowadays we can find these centres in various forms at all public universities. These centres are e.g. at the University of Economic in Prague ${ }^{2}$, at the Charles university ${ }^{3}$ or at the Czech Technical University in Prague ${ }^{4}$, which are all of the oldest in the Czech Republic.

This paper deals with the evaluation of study issues of various groups of students with some disadvantage. The analysis includes the access of these students to the study, the satisfaction with study and school, the living conditions, the evaluation of employment opportunities and their future plans. We want to try to describe students' feelings and behaviour and accordingly identify key problems of their study. We assume that all of mentioned groups of students have worse study condition compared to "normal" students.

The rest of paper is organized as follows. Firstly we introduce the survey Eurostudent V as the main data source and used statistical methods. Then we present the results of our analysis. The analysis includes the evaluating of the study conditions of students with any disadvantage. Finally we analyze financial situation of these students including their incomes and consumption expenditures. The aim of this paper is to verify the hypothesis on worse study conditions of disadvantaged students.

\section{Data and Methodology}

Our research is based on the data from survey EUROSTUDENT $\mathrm{V}^{5}$. This survey was conducted in all EU countries. The main aim of the project is to obtain comparable data on the

\footnotetext{
${ }^{1}$ http://www.vdv.cz/programy/vzdelani/fond-vzdelani/

${ }^{2} \mathrm{http}: / /$ shs.vse.cz/

${ }^{3} \mathrm{http}: / /$ www.cuni.cz/UK-60.html

${ }^{4}$ http://www.elsa.cvut.cz/media/prazska-technika-1-2013.pdf

${ }^{5}$ EUROSTUDENTV was realised within the project Ipn KREDO CZ.1.07/4.1.00/33.0005.
} 
social dimension of European tertiary education. It focuses on the socio-economic background and on the living conditions of students but it also investigates temporary international mobility. The project provides reliable and insightful cross-country comparisons. During 2013, the survey was conducted in the Czech Republic. It was focused on students in all public, state and selected private universities. 95,177 students were addressed in total. The data set consists of 4,664 responses from college students. The data were weighted according to data from the register of students.

The following analysis focuses on disadvantaged students including people from families with low social standing, handicapped or disadvantages people and studying mothers with children. They belong to "endangered species" of students.

The key question to identifying students from low social class is a subjective assessment of the social status of their parents. The question in EUROSTUDENT V was: "Evaluate the social status of your parents and place them on a scale of $0-10$, where $0=$ high social class and $10=$ low social class". The low class is determined by numbers 8,9 and 10 for purposes of this paper. We expect that the social class categories are correlated with parent's education and occupation.

Looking after the children is another important factor influencing the study conditions. In this paper, the mothers with children are represented by women studying bachelor and master studies with at least one child and the youngest child is less than 18 years old. We find out the satisfaction with their study and their financial situation.

The sample of students includes also handicapped students. We focus on their study conditions and problems with study and on their living conditions compared to "normal" health students.

The standard statistical and descriptive methods were used ${ }^{6}$. Because we worked especially with qualitative variables, we used contingency tables and the values of Cramer's $\mathrm{V}$ and Pearson contingency coefficients. If it is not otherwise mentioned, we verify the hypothesis about the dependency at $1 \%$ significance level.

\section{General Characteristics of Disadvantages Students}

The disadvantaged students consist of 1,156 students, which is one quarter of the whole sample. Every mentioned group of students has some specific characters.

\section{Students from families with low social status}

The low class consists of 200 students, which is $8 \%$ of the whole sample. The social status of the family is perceived as low especially by the students older than 30 years $(32.5 \%)$ and younger than 21 years $(26.5 \%)$. The students from families with low social status are most often graduated from vocational schools including lycées $(62 \%)$ and from secondary school $(35 \%)$. The subjective assessment of social status of family differs by field of study programs. The students of humanities and arts most often consider their social status as a low $(10.1 \%)$, on the other hand, the lowest proportion of students who feel the low social status of family comes from engineering field of study (5.3\%).

\section{Women with children}

Women represent $56 \%$ of all respondents. Only $9 \%$ women declared that have at least one child less than 18 years old. In most cases, studying mothers most have one child (41\%) or

\footnotetext{
${ }^{6}$ All computations were made in the program SPSS.
} 


\section{APPLICATIONS OF Mathematics and Statistics IN ECONOMICS}

two children (48\%). However, women with three or four children occurred in the sample. The average age of youngest child is about 7 years. An important factor affecting not only the number of children, but also the overall evaluation of the study itself, is age (Cramer's $\mathrm{V}=$ 0.655). $83 \%$ women with children are older than 30 years, $15 \%$ women are between $26-30$ years, and only $2.2 \%$ women with children are younger 25 years. Studying mother with children most often study combined studies at a private college. They prefer schools that are near their place of residence. They also emphasize the employability after graduation.

\section{Disabled students}

The students could choose one of more type of health or other disadvantage in the questionnaire. The following possibilities were - chronic diseases, psychic problems, physical problems, sensory problems (visual or auditory), learning disabilities (dyslexia, etc.) or other long-standing problem.

There are $13 \%$ students with any health disability in our sample. $83 \%$ disabled persons study in daily study. The most students deal with psychic problems $(30 \%)$ and with learning disabilities (28\%). On the contrary, least students suffer physical problems (10\%).

$11 \%$ of disabled students evaluate their problems as low handicap. Only 5\% students find their problems as great handicap. The psychic problems are the greatest restriction in study for disabled students, sensory problems surprisingly represent moderate problems in study. Almost half of disabled students don't need any institutional and public support. Disabled students who need some public support answered the question about satisfaction with this support. Students with sensory problems are mostly satisfied compared to students with psychic problems.

\section{The study conditions of disadvantaged students}

The analysis of contingency tables confirms the differences between feelings about belonging to college and particular groups of students ( $p$-value $=0.0008$, Cramer's V $=0.100$ ).

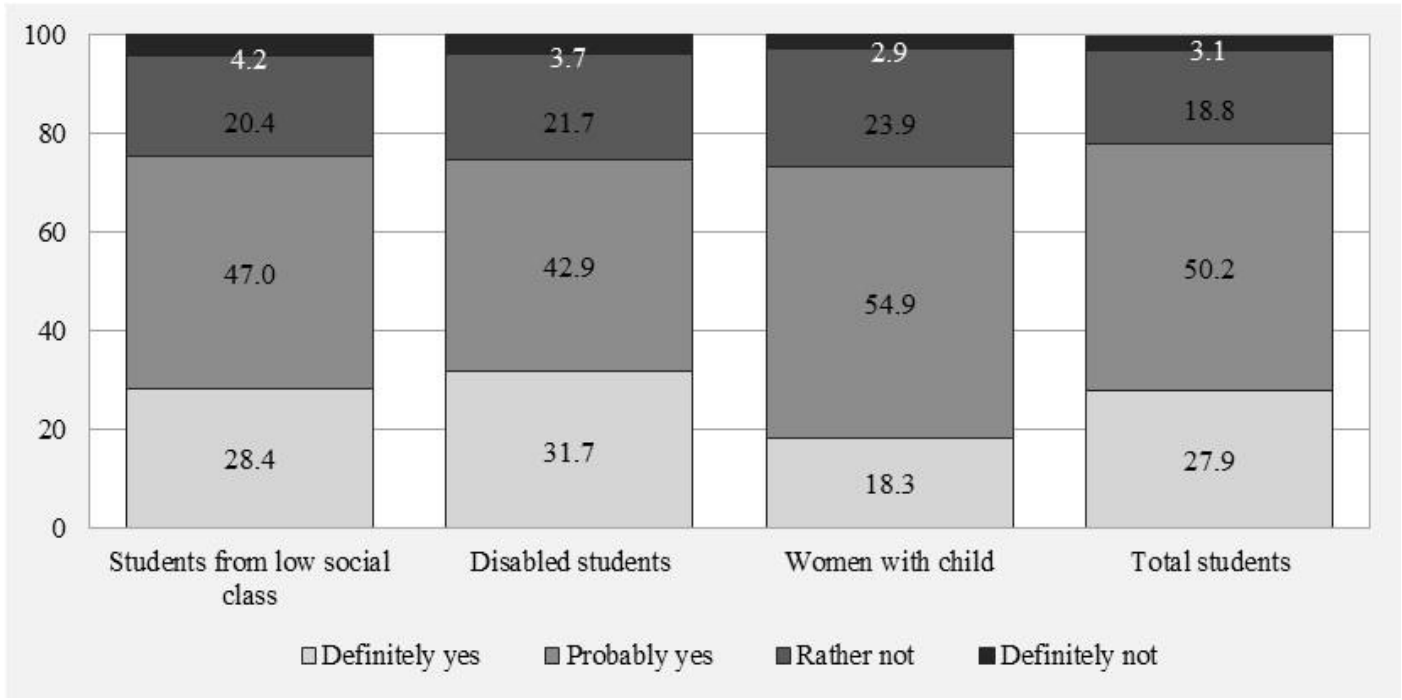

Figure 1 Feeling about belonging to college (\%)

Source: data from EUROSTUDENT V 


\section{APPLICATIONS OF Mathematics and Statistics IN ECONOMICS}

Students from families with low social status are not so closely connected to college compared to students from families with high social status. Similarly, women without children feel more to be a part of school than women with children. The good information seems to be that students with any disabilities do not feel excluded from college so much (see Figure 1). Women with small children have less feeling of belonging to college in comparison with other students

The students answered the question about the satisfaction with some issues of study in college, e.g. the organisation and schedule of study, the quality of education, school equipment, choice of courses or the approach of lectors and study referents. The evaluation of some issues is different between various groups of students ( $\mathrm{p}$-value $=0.0007$, Cramer's $\mathrm{V}=$ 0.205). Figure 2 shows the evaluation of quality of education in college. Women with children are more satisfied with the quality of education compared to disabled students and students from low social class. On the other hand, women with children are most dissatisfied with the possibility to choose from a wide range of subject. However, it can be caused by smaller choice of courses at private colleges where women with children very often study.

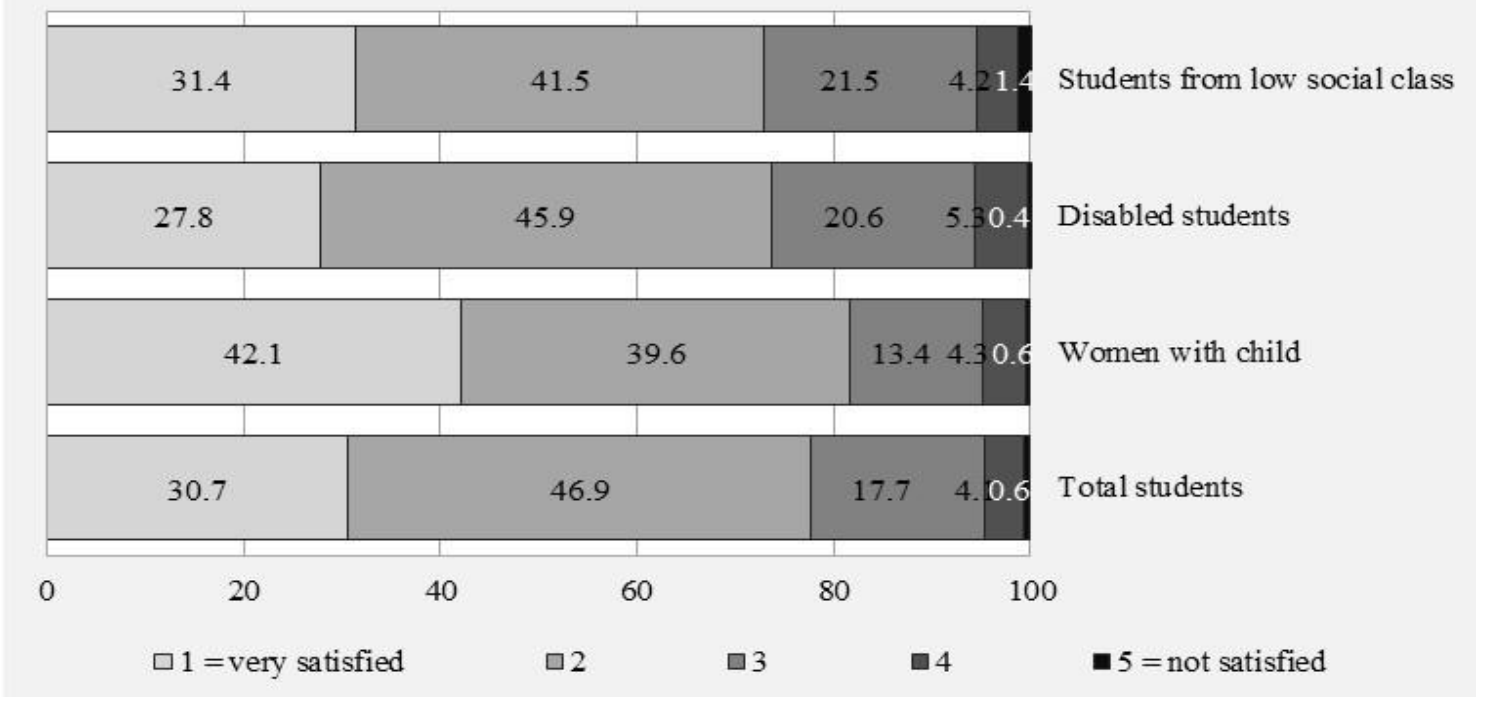

Figure 2 Satisfaction with the quality of education in college

Source: data from EUROSTUDENT V

Any substandard conditions of students influence their future plans ( $p$-value $=0.0004$, Cramer's $\mathrm{V}=0.095)$. Some students decide not to continue on the upper degree of study by reason of various considerations. Figure 3 shows plans for further studies of students in bachelor degree of study. Disabled students have a greatest ambition to further study. Only the half of women with children studying in bachelor degree wants to continue in upper degree. 


\section{APPLICATIONS OF Mathematics and Statistics \\ IN ECONOMICS}

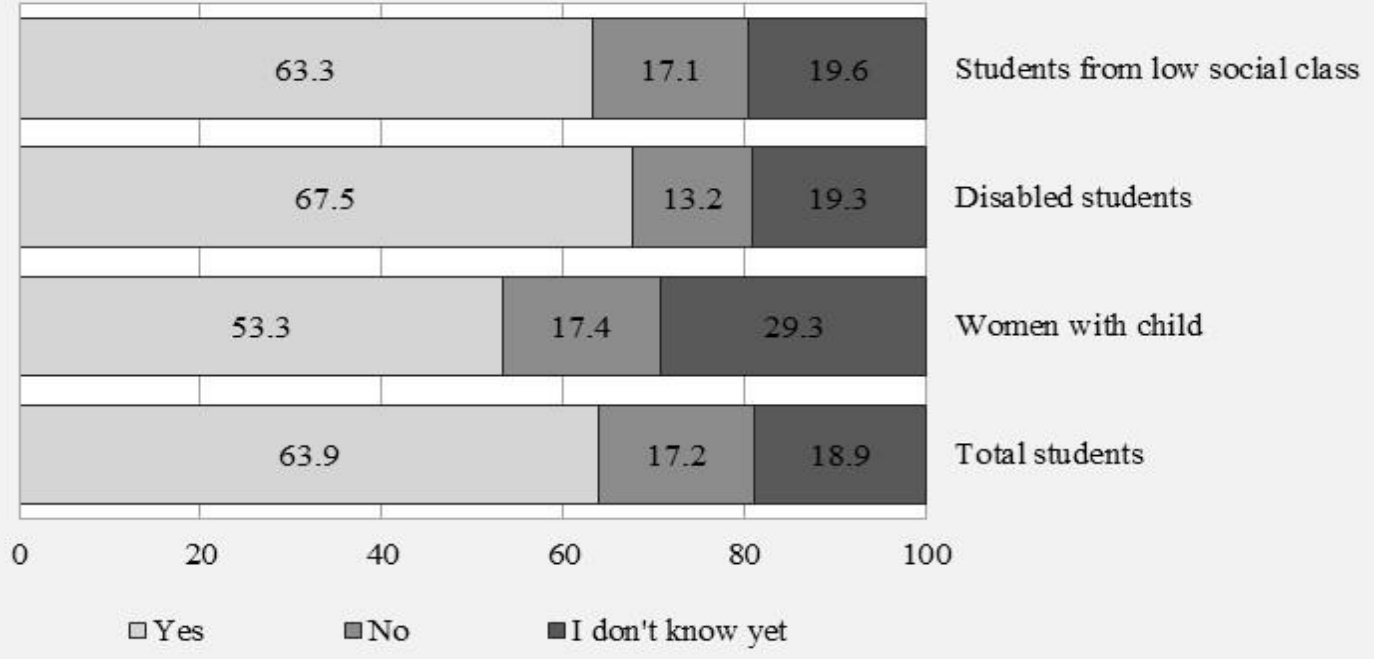

Figure 3 Future study plans

Source: data from EUROSTUDENT V

The economic situation of students is one of the reasons for work during the study. The work while studying may be positive activity when it is related to field of study. It could provide practice for students and increase their chances on the labour market. Unfortunately, this survey shows that about many students have work not related to their field of study. The analysis of contingency table confirms the dependency of connection between study and work on the disability of students (p-value $=0.000$, Cramer's $\mathrm{V}=0.171$ ). $37 \%$ of students from families with low social status have work not at all related to their field of study. The group of women with children has the greatest connection between study and work (35\%) in comparison with other mentioned groups of students (see Figure 4).

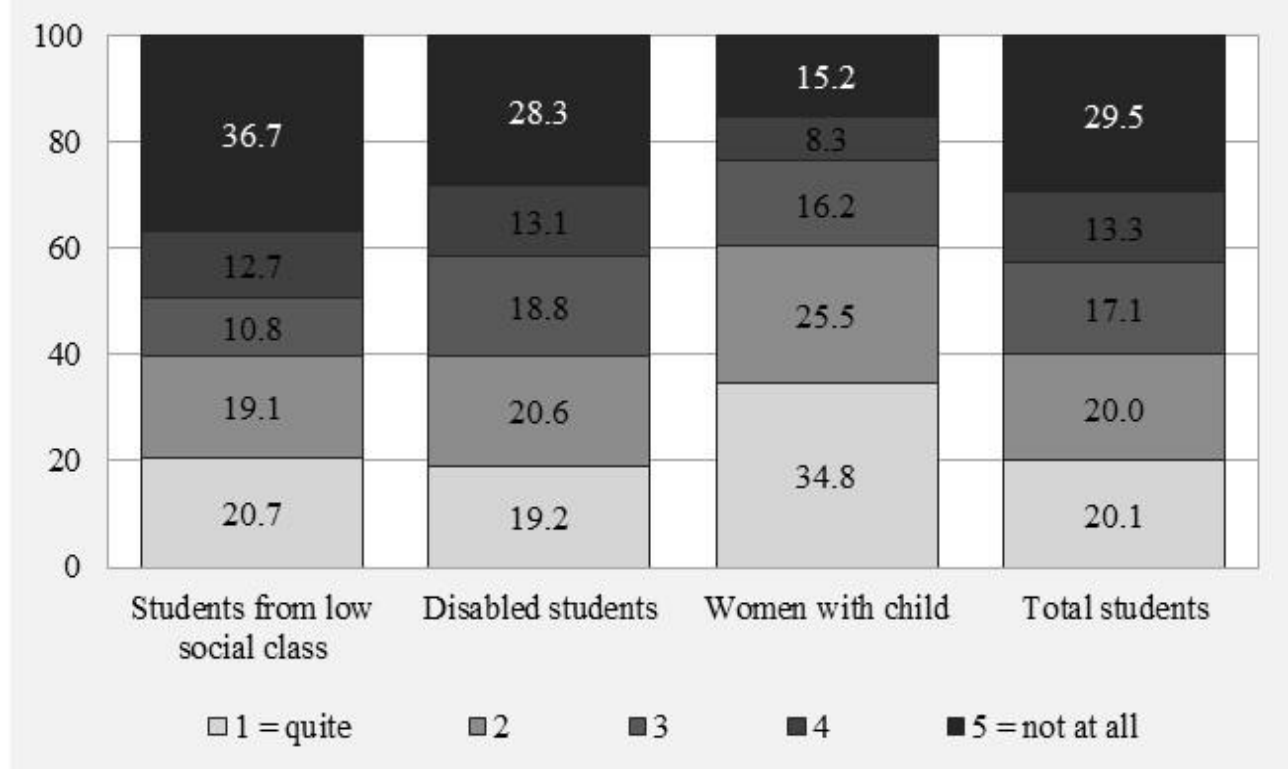

Figure 4 Connection between study and work (\%)

Source: data from EUROSTUDENT V 
It is interesting to compare the subjective evaluation of future opportunities at national labour market among various groups of students ( $\mathrm{p}$-value $=0.002$, Cramer's V $=0.105$ ). The students from low social class family consider their employment opportunities generally worse than other students (see Figure 5). The half of students from low social class evaluates their opportunities at national labour market as good or very good (in contrast to $70 \%$ of students from high social class). Women with children find their employment opportunities better than other students.

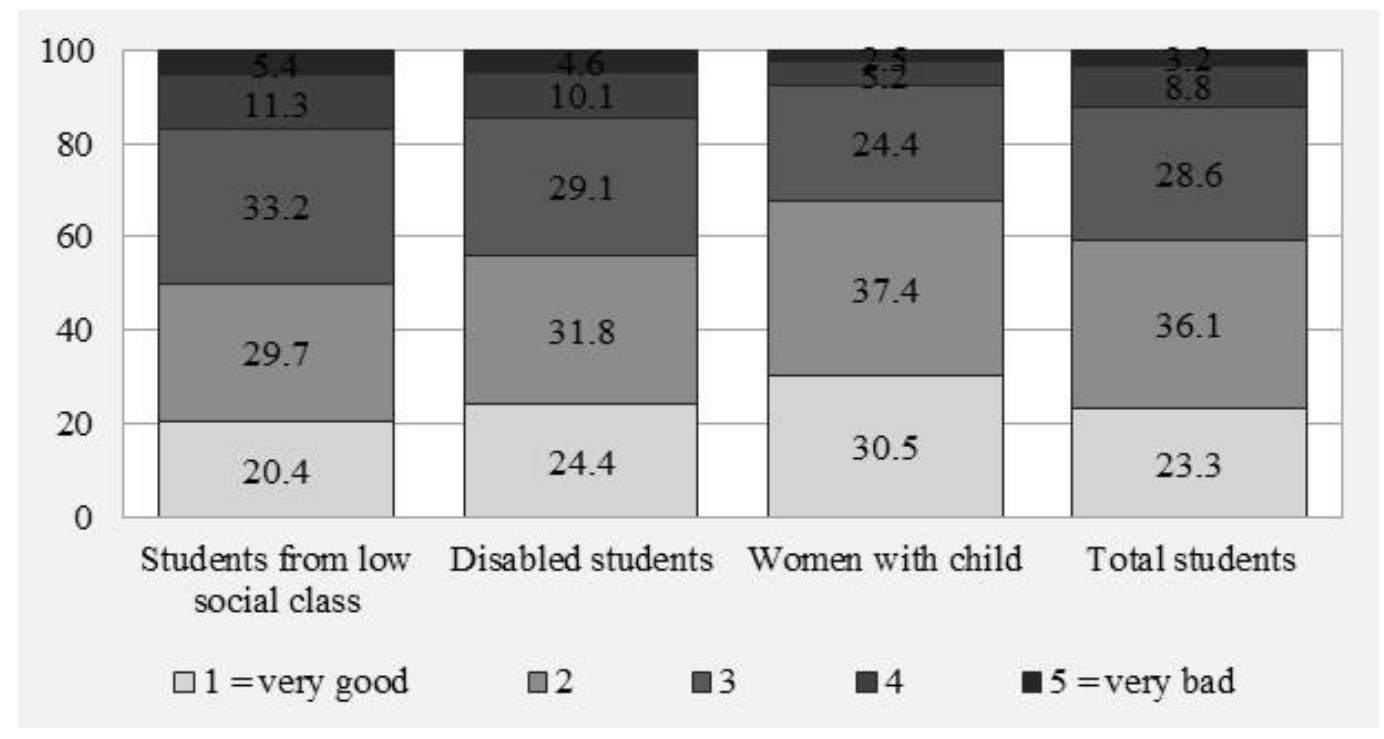

Figure 5 Subjective evaluation of opportunities at labour market (\%)

Source: data from EUROSTUDENT V

Statistically significant dependency is observed between the assessment the degree of troubles with finance and students' disadvantages (p-value $=0.0001$, Cramer's V $=0.113$. The lower is the social status of parents means higher proportion of students dealing with financial problems. Almost the half of women with children deals with financial problems (very serious or serious). Only $7 \%$ of disabled students do not deal with financial problems (Fischer and Vltavská, 2014).

\section{Life conditions of disadvantages students}

Financial situation is a very important issue in students' life. Therefore we also focus on the structure of students' incomes and expenditures. The following table shows the structure of financial resources of disadvantaged students. The average monthly amount of money gained from parents, partner or others ${ }^{7}$ is almost the same for all the examined groups of students. Women with children have the highest self-income compared to other groups of students (they represent $73 \%$ of total their income). Disabled students are more financially dependent on parents or partners.

\footnotetext{
${ }^{7}$ Other incomes originate from a non-refundable student grant, reversing student loan, public sources (pension, allowances) etc.
} 
Table 1 The structure of monthly incomes of students (in CZK)

\begin{tabular}{lccc}
\hline & $\begin{array}{c}\text { Students from } \\
\text { low social class }\end{array}$ & Disabled students & $\begin{array}{c}\text { Women with } \\
\text { children }\end{array}$ \\
\hline From parents/partner & 3047 & 3536 & 3195 \\
\hline Self-income & 9824 & 6049 & 15662 \\
\hline Others & 1787 & 1362 & 2625 \\
\hline Total & 14658 & 10947 & 21483 \\
\hline
\end{tabular}

Source: data from EUROSTUDENT V

Consumption expenditures of college students are currently one of the often discussed topics (e.g. in connection with introduction of tuition fees). According to the analysis of variance, the monthly expenditures depend on the social status of families, students' disabilities and motherhood.

The total amount of expenditures of students of low social class is 11,592 CZK on average, the expenditures of disabled students are $10,367 \mathrm{CZK}$ on average and the expenditures of women with children is $23,644 \mathrm{CZK}$ on average. Women with children are older on average with higher economic activity than other groups of students and therefore it is not surprising that mothers have twice higher expenses than others students (see Table 2).

The costs of university studies are very high for many families today. Food, living, books, transport, etc. - all these issues mean financial burden for students. The highest amount of students are spent for daily consumption and living. The total amount of expenditures of mothers is increased just by expenses on child care and on living.

Table 2 The structure of students' expenditures (in CZK)

\begin{tabular}{|c|c|c|c|c|c|c|}
\hline & \multicolumn{2}{|c|}{$\begin{array}{c}\text { Students from low } \\
\text { social class }\end{array}$} & \multicolumn{2}{|c|}{ Disabled students } & \multicolumn{2}{|c|}{$\begin{array}{l}\text { Women with } \\
\text { children }\end{array}$} \\
\hline & $\begin{array}{l}\text { Paid by } \\
\text { own } \\
\text { funds }\end{array}$ & $\begin{array}{l}\text { Paid by } \\
\text { someone } \\
\text { else }\end{array}$ & $\begin{array}{l}\text { Paid by } \\
\text { own } \\
\text { funds }\end{array}$ & $\begin{array}{c}\text { Paid by } \\
\text { someone } \\
\text { else }\end{array}$ & $\begin{array}{l}\text { Paid by } \\
\text { own } \\
\text { funds }\end{array}$ & $\begin{array}{c}\text { Paid by } \\
\text { someone } \\
\text { else }\end{array}$ \\
\hline Living & 2466 & 2063 & 1618 & 2449 & 5009 & 2902 \\
\hline Daily consumption & 1960 & 913 & 1517 & 1091 & 3960 & 1320 \\
\hline Transport & 845 & 237 & 596 & 340 & 1722 & 453 \\
\hline Phone, internet & 352 & 157 & 257 & 224 & 623 & 206 \\
\hline Medical care & 148 & 68 & 170 & 107 & 248 & 82 \\
\hline Child care & 549 & 78 & 160 & 35 & 2848 & 1101 \\
\hline Culture and leisure time & 694 & 100 & 618 & 166 & 1042 & 252 \\
\hline Others & 780 & 182 & 736 & 283 & 1449 & 428 \\
\hline Total & 7794 & 3798 & 5672 & 4695 & 16901 & 6743 \\
\hline
\end{tabular}

Source: data from EUROSTUDENT V

If we had a look at structure of expenditures according to person who is paying them, we found a significant difference between amount paid by own funds and amount paid by someone 
else. All students regardless of any disadvantage have higher amount of expenditures paid by own funds, however, the amount of expenditures paid by someone else is still significant. Mothers have the highest expenditures paid by own funds (72\%). Almost 50\% of expenditures of disabled students are paid by someone else. Regarding to expenditures, we assume that our systems count on (at least minor) financial support from parents.

\section{Conclusion}

The results of the analysis show that students with any disabilities and students coming from low social class do not feel excluded from college. Their feelings about belonging to the college are not mostly dependent on disability of students or social situation. Disabled students and students coming from low social class also have a greatest ambition to further study. Actually the percentage of disabled students who wish to continue is larger than other students. Women with small children have worse feelings about belonging to college in comparison with other students. Women with children are more satisfied with the quality of education and better evaluation of opportunities on labour market compared to disabled students and students from low social class.

In general, disabled students and student coming from low class have financial problems, and they do not believe in the chances of finding a job but it feels to be part of the school. In the future, educational policy should focus on creating jobs and support for disabled students and students from lower social classes. Schools should promote more the relationship between the practice and these students.

Mothers with children have better financial situation and they are more confident. Mostly they have to study in private school. Public school does not offer distance study so much. Women with children do not feel much support from the school. The solution of this situation would to lie in the increase the number of programs offered in the distance form, more flexible schedule or offer babysitting during the school day. Generally, the colleges would strive to improve the learning environment for all types of students, some problems are invisible for "normal" students without any disadvantage. Some solutions exist, e.g. flexible schedule or nursery school, however there are a lot of other things to improve in future.

\section{Acknowledgements}

The paper has been prepared under the support of the University of Economics, Prague Internal Grant Agency; project No. IGA 9/2013 'Quantification of the impact of education policy of the last decade in the light of Census 2011 results"

\section{References}

1. Cullinan, John, Flannery, Darragh, Walsh, Sharon (2013). Distance Effects, Social Class and the Decision to Participate in Higher Education in Ireland, Economic and Social Review, Vol. 44, No. 1, Pg 19 - 51, ISSN: 0012-9984

2. CZSO (2012). Publikace Studenti a absolventi vysokých škol v České republice v roce 2012, [online] Český statistický úřad, http://www.czso.cz/csu/redakce.nsf/i/studenti_a_absolventi_vysokych_skol_v_cr_celkem

3. Dömeová Ludmila, Vydrová Hana, Jidrová Andrea (2010). Women in distance studies, In: Efficiency and Responsibility in Education, Praha: Czech University of Life Sciences in Prague, pg. 71 - 78, ISBN: 978-80-213-2084-0. 
4. Fischer, Jakub, Lipovská, Hana (2013). How Does the Parents' Attained Level of Education Influence Lifelong Learning of Children? In: Efficiency and Responsibility in Education. Praha: Czech University of Life Sciences in Prague, pg. 128 - 135, ISBN: 978-80-213-2378-0.

5. Fischer Jakub, Vltavská Kristýna, et al. (2014). EUROSTUDENT V: Základní výsledky šetření postojů životnich podminek student vysokých škol v České republice [online] Ministerstvo školství, mládeže a tělovýchovy, http://kredo.reformy-msmt.cz/vysledkyeurostudent- $\mathrm{v}$

6. Hadjikakou, Kika (2012). Improving disabled students' learning: experiences and outcomes. International journal of disability development and education, ISSN: 1034-912X, Vol. 59, No 1, pp. 125 - 126.

7. Jencks Christopher et al. (1973). Inequality: A Reassessment of the Effect of Family and Schooling in America, Harper Row, ISBN: 978-0061319600.

8. Mazouch Petr, Fischer Jakub (2011). Lidský kapitál: Měrení, souvislosti, prognózy, Praha: C. H. Beck, ISBN: 978-80-7400-380-6.

9. Riddell, Sheila, Tinklin Teresa, Wilson Alastair (2005). New Labour, Social Justice and Disabled Students in Higher Education, British Educational Research Journal, Vol. 31, No. 5, Education Policy and Social Justice. pp. 623 - 643.

10. Scott Catherine, Burns Ailsa, Cooney George (1998). Motivation for return to study as a predictor of completion of degree amongst female mature students with children, Higher Education, Volume 35, Issue 2, pp 221 - 239, ISSN: 0018-1560.

11. Sewell William. H. (1971). Inequality of Opportunity for Higher Education, American Sociological Review, Vol. 36, Issue 5, pp. 793 - 809.

12. Tiu Wu Aimee (2013). Learning to balance: exploring how women doctoral, Students navigate school, motherhood and employment, Columbia University, Dissertation. 